\title{
EFEKTIVITAS AROMATERAPI LAVENDER UNTUK MENGURANGI KECEMASAN MENGHADAPI PERSALINAN PADA IBU HAMIL TRIMESTER III DI WILAYAH KERJA PUSKESMAS BERGAS
}

\author{
Galuh Nila $S^{1}$, Wahyu Kristiningrum ${ }^{2}$, Luvi Dian Afriyani ${ }^{3}$ \\ Program Studi DIV Kebidanan, Universitas Ngudi Waluyo, Ungaran \\ Email : galuhg407@gmail.com
}

\begin{abstract}
ABSTRAK
Kecemasan antenatal selama kehamilan merupakan faktor resiko terjadinya depresi postpartum. Kecemasan pada trimester tiga dapat mempengaruhi proses persalinan, tumbuh kembang anak, kelahiran prematur, BBLR, partus lama dan gangguan mental. Aromaterapi adalah salah satu bagian dari pengobatan alternatif yang menggunakan bahan cairan tanaman yang mudah menguap, dapat mempengaruhi jiwa, emosi, dan fungsi kognitif serta kesehatan sesorang. Mengetahui efektivitas aromaterapi lavender untuk mengurangi kecemasan menghadapi persalinan pada ibu hamil trimester III di Wilayah Kerja Puskesmas Bergas. Desain penelitian yaitu Pre-Experiment, dengan rancangan one group pre test posttest. Populasi dalam penelitian ini adalah seluruh ibu hamil Trimester III di Wilayah Kerja Puskesmas Bergas. Teknik sempling menggunakan Kuota Sampling dengan jumlah responden 15 ibu hamil. Uji statistik yang digunakan adalah Uji t-test dependent. Mean kecemasan sebelum diberikan aromaterapi lavender adalah 18,07 dengan nilai maksimum 22 dan nilai minimum 14. Mean kecemasan setelah diberikan aromaterapi lavender adalah 14,53 dengan nilai maksimum 18 dan nilai minimum 10. Aromaterapi lavender efektif untuk mengurangi kecemasan menghadapi persalinan pada ibu hamil trimester III dengan $p$ value $=0,000$ $\leq$ 0,05.Aromaterapi lavender efektif untuk mengurangi kecemasan menghadapi persalinan pada ibu hamil trimester III di Wilayah Kerja Puskesmas Bergas.
\end{abstract}

\section{Kata Kunci : Aromaterapi Lavender, Kecemasan Ibu Hamil Trimester III}

\section{ABSTRACT}

Effectiveness of Lavender Aromatherapy to Reduce Anxiety Before Labor in Third Trimester Pregnant Mothers in The Bergas Community Health Center Working Area

Antenatal anxiety during pregnancy is a risk factor for postpartum depression. Anxiety in the third trimester can affect baby delivery, child growth, premature birth, low birth weight, prolonged baby delivery and mental disorders. Aromatherapy is one part of alternative medicine that uses volatile plant fluids, can affect the soul, emotions, and cognitive functions and health of someone. To examine the effectiveness of lavender aromatherapy to reduce anxiety of facing baby delivery in third trimester pregnant women in the Working Area of Public Health Center of Bergas. The research design was Pre-Experiment, with the design of the one group pre test post test. The population in this study were all Trimester III pregnant women in the Working Area of Public Health Center of Bergas. The sampling technique used Quota Sampling with the number of respondents 15 pregnant women. The statistical test used the dependent $t$ test. The mean anxiety before being given lavender aromatherapy was 18.07 with a maximum value of 22 and a minimum value of 14. The mean anxiety after being given

Efektivitas Aromaterapi Lavender.. (Galuh Nila S, Wahyu Kristiningrum, Luvi Dian Afriyani) 
lavender aromatherapy was 14.53 with a maximum value of 18 and a minimum value of 10. Lavender is an effective aromatherapy to reduce anxiety of facing baby delivery in third trimester pregnant women with $p$ value $=0,000 \leq 0.05$. Lavender aromatherapy is effective to reduce anxiety of facing baby delivery in third trimester pregnant women in the Working Area of Public Health Center of Bergas.

\section{Keywords : Lavender Aromatherapy, Trimester III Pregnant Women's Anxiety}

\section{PENDAHULUAN}

Angka Kematian Ibu (AKI) juga menjadi salah satu indikator penting penentu derajat kesehatan masyarakat (DKK, 2017). Berdasarkan laporan Puskesmas, Angka Kematian Ibu di kabupaten Semarang pada tahun 2017 mengalami peningkatan dibandingkan tahun 2016. Bila ditahun 2016 AKI sebesar 103,39 per $100.000 \mathrm{KH}$ (14 kasus), maka di tahun 2017 menjadi 111,83 per $100.000 \mathrm{KH}$ (15 kasus).

Penyebab kematian tertinggi terjadi pada saat ibu bersalin (8 kasus) yang disebabkan karena perdarahan sebanyak 6 kasus dan diikuti penyebab tertinggi kedua yaitu pre eklamasia/eklamsia dengan jumlah 5 kasus, gagal ginjal 1 kasus, TB paru diare kronis 2 kasus. Kematian ibu terbesar terjadi pada ibu dengan tingkat pendidikan SMA (8 kasus) dan terjadi pada ibu dengan usia 31-35 tahun (5 kasus). Upaya yang telah dilakukan untuk menekan Angka Kematian Ibu (AKI) antara lain dengan melaksanakan Program Maternal and Infant Mortality Meeting (M3) dari tingkat desa sampai tingkat kabupaten, meningkatkan jejaring ibu bayi selamat dengan sistem rujukan, upaya deteksi dini ibu hamil dengan Program Perencanaan Persalinan dan Pencegahan Komplikasi (P4K) dan Antenatal Care (ANC) terintegrasi, serta meningkatkan keterampilan dan pengetahuan petugas dengan berbagai pelatihan termasuk Asuhan Persalinan Normal (APN) dan Pertolongan Pertama Kegawatdaruratan Obtetric dan Neonatus (PPGDON) serta optimalisasi puskesmas PONED
(Pelayanan Obtetric dan Neonatal Emergency Dasar). Selain itu juga dibentuk Satgas Penurunan AKI, mengoptimalkan jejaring dan nomor telepon Call Center untuk penanganan kasus obtetric dan neonatal. Upaya lain Penyeliaan fasilitas terhadap bidan Monev Tim Gadar RS ke puskesmas PONED, On Job training Tim Puskesmas Rawat Inap ke RS PONEK, koordinasi Lintas Program, Lintas Sektor dan peningkatan Kesehatan keluarga, RTK Jampersal, WA Gateway untuk komunikasi rujukan obstetric neonatal dan juga kegiatan konsultasi ahli (DKK, 2017).

Kehamilan adalah suatu keadaan, di mana janin yang dikandung di dalam tubuh wanita yang diawali dengan proses pembuahan dan di akhiri dengan proses persalinan (Yohana, dkk, 2011). Masa kehamilan di mulai dari pembuahan hingga lahirnya janin. Lamanya kehamilan normal adalah 280 hari (40 minggu atau 9 bulan lebih 7 hari) di hitung mulai dari hari pertama haid terakhir (HPHT). Kehamilan dibagi dalam 3 triwulan (trimester) yaitu triwulan perama yang di mulai dari proses pembuahan sampai usia kehamilan 3 bulan, triwulan kedua dimulai dari bulan keempat hingga usia kehamilan 6 bulan, triwulan ketiga dimulai dari bulan ketujuh hingga bulan kesembilan (Pudiastuti, 2012).

Kecemasan pada ibu disebabkan karena adanya rasa takut terhadap kesehatan, usia kehamilan, kesulitan keuangan, dan masalah pokok lain dalam kehidupan. Kecemasan yang dialami ibu antara lain kecemasan 
terhadap persiapan persalinan karena sudah memasuki trimester III sehingga ibu akan terlalu mempersalahkan kesehatan serta cemas akan kondisi bayinya (Suprijati, 2014). Kecemasan antenatal selama kehamilan merupakan faktor resiko terjadinya depresi postpartum. Kecemasan pada kehamilan dapat pula menyebabkan kelahiran premature. Selain itu kecemasan selama kehamilan sampai trimester ketiga mempengaruhi proses persalinan, pertumbuhan perkembangan anak, lahir prematur, berat badan lahir rendah (BBLR), partus lama, gangguan mental dan motorik anak (Mardjan 2016). Keadaan ini menyebabkan gangguan dalam proses persalinan. Untuk mengatasinya, seorang ibu perlu mendapatkan intervensi dengan berbagai metode semasa antenatal guna meringankan beban psikologi terutama kecemasan pada trimester ketiga sampai menjelang persalinan (Mardjan, 2016). Upaya untuk menurunkan kecemasan pada ibu dapat menggunakan metode farmakologi dan nonfarmakologi. Metode farmakologi yaitu dengan obat-obatan fluoksetin $1 \mathrm{x}$ $10 \mathrm{mg}$ dan/atau alprazolam $2 \times 0,25 \mathrm{mg}$, namun penggunaan obat sering menimbulkan efek samping dan kadang obat tidak memiliki kekuatan efek yang diharapkan. (Kandace dkk, 2017). Sedangkan metode nonfarmakologi, dapat meningkatkan kepuasan selama persalinan, karena ibu dapat mengontrol perasakkannya dan kekuatannya. Relaksasi, teknik pernafasan, pergerakan dan perubahan posisi, massage, hidroterapi, terapi panas atau dingin, musik, guided imagery, akupresur dan aromaterapi merupakan beberapa teknik nonfarmakologi yang dapat meningkatkan kenyamanan ibu saat bersalin serta berpengaruh pada koping yang efektif terhadap pengalaman persalinan (Kandace dkk, 2017).
Aromaterapi adalah salah satu bagian dari pengobatan alternatif yang menggunakan bahan cairan tanaman yang mudah menguap, dikenal sebagai minyak esensial dan senyawa aromatik lainnya yang mempengaruhi jiwa, emosi, dan fungsi kognitif dan kesehatan seseorang (Nurgiwiati, 2015). minyak esensial dari ekstrak bunga lavender adalah sebagai aromaterapi yang memberi efek relaksasi, antineurodepresive dan sedasi untuk orang yang mengalami insomnia serta memperbaiki mood seseorang, menurunkan tingkat kecemasan, meningkatkan tingkat kewaspadaan. Senyawa polifenol yang terdapat dalam bunga lavender memiliki potensi sebagai antioksidan, menghambat aktivitas radikal bebas, anti-terbakar, antivirus, anti kanker, dan penyakit yang berhubungan dengan jantung dimana kandungan terbanyak adalah linaly asetat dan linalool yang dapat memberikan efek rileksasi (Pusat Studi Biofarmaka, 2014).

Hasil wawancara yang dilakukan pada 20 ibu hamil yang melakukan ANC sebanyak 15 ibu hamil mengalami gejala kecemasan menjelang persalinan seperti ibu menjadi susah tidur, tidur tidak nyenyak, cemas karena proses persalinan yang lalu yang mengalami penyulit, nyeri persalinan, takut anak yang dilahirkan cacat (jasmani maupun rohani), masalah biaya persalinan, usia serta faktor lingkungan. Selama ini Ibu hamil yang mengalami kecemasan mengatasinya dengan selalu berfikir positif dan ada juga yang mengatasinya dengan cara selalu berdoa kepada Allah dan memohon yang terbaik untuk ibu dan bayinya. Setelah melakukan beberapa hal tersebut terkadang ibu mengalami rasa tenang, namun tidak jarang kecemasan kembali muncul atau dirasakan ibu.

Berdasarkan uraian diatas, maka peneliti tertarik untuk melakukan 
penelitian dengan judul "Efektivitas aromaterapi lavender untuk menguramgi kecemasan menghadapi persalinan pada ibu hamil trimester III di Wilayah Kerja Puskesmas Bergas".

\section{SUBJEK DAN METODE}

Metode penelitian yang digunakan adalah Pre-Experiment dengan desain one group pretest posttest untuk mengetahui efetivitas aromaterapi lavender terhadap kecemasan menghadapi persalinan pada ibu hamil trimester III di Wilayah Kerja Puskesmas Bergas. Populasi dalam penelitian ini adalah seluruh ibu hamil Trimester III di Wilayah Kerja Puskesmas Bergas sebanyak 83 ibu hamil. Pengambilan sampel menggunakan Kuota Sampling dengan jumlah sampel 15 ibu hamil trimester III. Kriteria inlusi sampel adalah Ibu hamil trimester III yang mengalami kecemasan, sehat jasmani dan rohani, sedangkan kriteria ekslusinya ibu hamil yang memiliki penyakit penyerta kehamilan seperti penyakit asma, alergi pernafasan, penyakit paru-paru kronis, tuberkulosis paru, dan memiliki alergi terhadap aromaterapi lavender.

Instrumen penelitian ini menggunakan kuisioner Hamilton Anxiety Rating Scale (HARS) (Efitriasih, 2017). Untuk mengetahui distribusi normal atau tidak dilakukan uji normalitas (Notoatmojo, 2012). Uji normalitas menggunakan uji shapiro wilk dan didapatkan hasil $p$ value kecemasan pretest 0,535 dan posttest $0,605>\alpha=0,005$ sehingga didapatkan distribusi normal. Untuk mengetahui efektivitas aromaterapi lavender untuk menurunkan kecemasan menghadapi persalinan pada ibu ibu hamil trimester III di Wilayah Kerja Puskesmas Bergas digunakan uji dependent t-test.

\section{HASIL}

Karakteristik Responden

Tabel 1 Deskripsi Berdasarkan Umur Ibu Hamil Trimester III di Wilayah Kerja Puskesmas Bergas

\begin{tabular}{cccccc}
\hline Variabel & $\mathbf{N}$ & Mean & SD & Min & Max \\
\hline Umur & 15 & 27,60 & 4,763 & 22 & 39 \\
\hline
\end{tabular}

Puskesmas Bergas, rata-rata berumur 27

Berdasarkan tabel 4.1 dapat diketahui bahwa dari 15 responden ibu tahun, dengan umur paling muda 22 tahun dan umur paling tua 39 tahun. hamil trimester III di Wilayah Kerja

Tabel 2 Deskripsi Berdasarkan Paritas Ibu Hamil Trimester III di Wilayah Kerja Puskesmas Bergas

\begin{tabular}{cccccc}
\hline & Frequency & Precent & $\begin{array}{c}\text { Valid } \\
\text { Precent }\end{array}$ & $\begin{array}{c}\text { Vumulative } \\
\text { precent }\end{array}$ \\
\hline \multirow{2}{*}{ Valid } & Primigravida & 7 & 46,7 & 46,7 & 46,7 \\
\cline { 2 - 6 } & Multigravida & 8 & 53,3 & 53,3 & 100,0 \\
\cline { 2 - 6 } & Total & 15 & 100,0 & 100,0 \\
\hline \multirow{2}{*}{ Berdasarkan tabel di atas total } & \multicolumn{2}{c}{$\begin{array}{c}\text { kedalam primigravida ada } 7 \text { ibu humil } \\
\text { dan multigravida ada } 8 \text { ibu hamil. }\end{array}$}
\end{tabular}
ibu hamil trimester III di Wilayah Kerja Puskesmas Bergas yang termasuk

\section{Analisa Univariat}

Tabel 3 Kecemasan menghadapi persalinan pada ibu hamil trimester III sebelum diberikan aromaterapi lavender di Wilayah Kerja Puskesmas Bergas 


\begin{tabular}{|c|c|c|c|c|c|}
\hline Variabel & $\mathbf{N}$ & Mean & SD & Min & Max \\
\hline Kecemasan & 15 & 18,07 & 2.463 & 14 & 22 \\
\hline
\end{tabular}
responden yang belum diberikan

Tabel 4 Kecemasan menghadapi persalinan pada ibu hamil trimester III setelah diberikan aromaterapi lavender di Wilayah Kerja Puskesmas Bergas

\begin{tabular}{cccccc}
\hline Variabel & N & Mean & SD & Min & Max \\
\hline Kecemasan & 15 & 14,53 & 2.326 & 10 & 18 \\
\hline \multirow{2}{*}{ Berdasarkan tabel diatas dapat } & & 18, nilai & minimum & 10 & dan rata-rata
\end{tabular}

diketahui nilai tingkat kecemasan pada responden yang telah diberikan

Analisa Bivariat

perlakuan mempunyai nilai maksimum

Tabel 4.6 Efektivitas Aromaterapi Lavender Untuk Mengurangi Kecemasan Menghadapi Persalinan pada Ibu Hamil Trimester III di Wilayah Kerja Puskesmas Bergas

\begin{tabular}{ccccccc}
\hline Variabel & Perlakuan & n & Mean & SD & T & p-value \\
\hline Kecemasan & Sebelum & 15 & 18,07 & 2,463 & 16,412 & 0,000 \\
\hline & Sesudah & 15 & 14,53 & 2,326 & & \\
\hline
\end{tabular}

Berdasarkan tabel 4.6, dapat diketahui bahwa sebelum diberikan Aromaterapi Lavender, rata-rata skor kecemasan menghadapi persalinan pada ibu hamil trimester III sebesar 18,07, kemudian turun menjadi 14,53 setelah diberikan Aromaterapi Lavender.

Berdasarkan uji dependent t-test, didapatkan nilai t hitung sebesar 16,412 dengan $p$-value $0,000<\alpha(0,05)$, ini menunjukan bahwa ada perbedaan kecemasan menghadapi persalinan pada ibu hamil trimester III sebelum dan sesudah diberikan Aromaterapi Lavender di Wilayah Kerja Puskesmas Bergas.

\section{PEMBAHASAN}

Kecemasan merupakan reaksi yang normal terhadap situasi yang sangat menekan kehidupan seseorang.
Cemas adalah suatu emosi yang sejak dulu dihubungkan dengan kehamilan, yang hubungan ini tidak jelas. Umumnya kecemasan dan kekhawatiran berhubungan dengan kesehatan dan keselamatan, ibu hamil cemas terhadap kemungkinan komplikasi waktu hamil dan bersalin, cemas terhadap nyeri waktu bersalin, kekhawatiran tidak segera memperoleh pertolongan ataupun perawatan semestinya dan cemas terhadap ancaman bahaya maut yang menyertai saat persalinan tiba. Selain itu, dapat timbul rasa cemas yang tidak langsung berhubungan dengan proses kehamilannya, misalnya soal rumah tangga, mata pencaharian suami atau mengenai hubungan dengan suami. Kecemasan terhadap bayi yang akan dilahirkan misalnya mengenai cacat, perlukaan, keguguran, kematian dalam kandungan, kemungkinan melahirkan anak kembar, dan juga kapasitas anaknya. Berbagai perasaan cemas ini akan mudah timbul apabila ibu hamil sendiri telah mengalami, melihat 
ataupun mendengar hal-hal yang tidak diinginkan telah menimpa tetangganya, saudaranya atau temannya (Susanti, 2008).

Kecemasan ibu hamil dalam menghadapi persalinan tersebut akan selalu diikuti nyeri kemudian akan mengakibatkan peningkatan kerja sistem saraf simpatik, dalam situasi ini sitem endokrin yang terdiri dari kelenjar-kelenjar seperti adrenal, tiroid, dan pituitary (pusat pengendalian kelenjar), melepaskan pengeluaran hormon masing-masing ke aliran darah dalam rangka mempersiapkan badan pada situasi darurat. Akibatnya, sistem syaraf atonum mengaktifkan kelenjar adrenal yang mempengaruhi sistem pada hormon epinefrin. Peningkatan hormon adrenalin dan nonadrenalin atau epinefrin dan nonepinefrin menimbulkan disregulasi biokimia tubuh, sehingga muncul ketegangan fisik pada diri ibu hamil yang menyebabkan ibu hamil menjadi mudah marah atau tersinggung, gelisah, tidak mampu memusatkan perhatian, raguragu, behakan kemungkinan lanjut akan membentuk suatu siklus umpan balik yang dapat meningkatkan intensitas emosional secara keseluruhan (Dariyo dalan Heni Efitriasih, 2017).

Aromaterapi adalah salah satu bagian dari pengobatan alternatif yang menggunakan bahan cairan tanaman yang mudah menguap, dikenal sebagai minyak esensial dan senyawa aromatik lainnya yang mempengaruhi jiwa, emosi, dan fungsi kognitif dan kesehatan seseorang (Nurgiwiati, 2015). Minyak esensial meningkatkan suasana hati dan mengurangi kecemasan selama persalinan dengan cara merangsang penciuman dalam sistem limbik (Bastard 2006). Minyak atsiri adalah diserap abmelalui inhalasi, mempengaruhi enzim dan kanal ion dan reseptor, dan akhirnya merangsang otak. Mereka maka dapat mengurangi kecemasan, memiliki efek antidepresan, dan meningkatkan sirkulasi darah di otak. Aromaterapi secara inhalasi juga memungkinkan minyak ini untuk menyeberangi penghalang darah-otak dan berinteraksi dengan reseptor sistem saraf pusat (Namazi, 2014). Aromaterapi dapat mempengaruhi sistem limbik di otak yang merupakan pusat emosi, suasana hati atau mood, dan memori untuk menghasilkan bahan neurohormon endorphin dan encephalin, yang bersifat sebagai penghilang rasa sakit dan serotonin yang berefek menghilangkan ketegangan atau stres serta kecemasan menghadapi persalinan. Lavender mempunyai efek menenangkan. Aroma lavender dapat memberikan ketenangan, keseimbangan, rasa nyaman, rasa keterbukaan dan keyakinan. Disamping itu, lavender juga dapat mengurangi rasa tertekan, stres, rasa sakit, emosi yang tidak seimbang, hysteria, rasa frustasi dan kepanikan (Setiati, 2019). Selain itu aromaterapi mudah untuk diterapkan, akting cepat dan dapat digunakan dalam intervensi keperawatan mandiri (Cho, 2013).

Hal ini sesuai dengan hasil penelitian yang dilakukan Kandace, dkk (2017) dimana ada pengaruh yang signifikan terhadap penurunan tingkat kecemasan ibu hamil trimester III menjelang persalinan. Aromaterapi digunakan untuk mempengaruhi emosi seseorang dan membantu meredakan penyakit. Minyak esensial yang digunakan dalam aromaterapi ini berhasiat untuk mengurangi stress, melancarkan sirkulasi darah, meredakan nyeri, mengurangi bengkak, menyingkirkan zat racun dari tubuh, mengobati infeksi virus, insomnia (sukar tidur) dan penyakit lainnya.

Berdasarkan hasil penelitian

dapat diketahui bahwa dari 15 responden, yaitu pre test dengan ratarata (mean) 18,07 dan kecemasan post 
test dengan rata-rata (mean) 14,53 dan dengan mengetahui uji parametris dimana diperoleh nilai $p$ value $0,000<$ $\alpha 0,05$, hal ini berarti aromaterapi lavender efektif untuk mengurangi kecemasan menghadapi persalinan pada ibu hamil trimester III.

Aromaterapi inhalasi terhadap minyak esensial dapat meningkatkan kesadaran dan menurunkan kecemasan. Molekul-molekul bau yang terkandung dalam minyak esensial memberikan efek positif pada sistem saraf pusat, yaitu dapat menghambat pengeluaran Adeno Corticotrophic Hormone $(\mathrm{ACTH})$, dimana hormon ini dapat mengakibatkan terjadinya kecemasan pada seseorang (Widiyono, 2013). Kandungan Linalool dan linalyl asetat dalam aromaterapi laevender memiliki maksimum dan besar sifat menyerap dari kulit selama pijat dengan depresi sistem saraf pusat. Linalool menunjukkan efek sedatif dan linalyl asetat menunjukkan tindakan narkotika ditandai. Kedua tindakan mungkin bertanggung jawab untuk penggunaannya pada pasien bantal kecemasan lavender dengan pola gangguan tidur, meningkatkan rasa kesejahteraan, mendukung kewaspadaan mental dan menekan agresi dan kecemasan (Ali 2015).

Hal tersebut sesuai dengan penelitian Setiati, dkk (2019) dimana terapi dengan menggunakan minyak esensial lavender dapat membantu membangkitkan semangat dan menyegarkan. Pemberian aromaterapi lavender efektif menurunkan kecemasan persalinan. Aromaterapi memiliki beberapa molekul yang dilepaskan keudara sebagai uap air. Ketika uap air yang mengandung komponen kimia tersebut dihirup, akan diserap tubuh melalui hidung dan paru-paru yang kemudian masuk kealiran darah. Bersamaan saat dihirup, uap air akan berjalan dengan segera ke sistem limbik otak yang bertanggung jawab dalam sistem integrasi dan perasaan, belajar, ingatan, emosi serta rangsangan fisik. Minyak esensial lavender sangat efektif dan bermanfaat saat dihirup atau digunakan pada bagian luar, karena indra penciuman berhubungan dekat dengan emosi manusia. Saat aroma dari minyak esensial lavender dihirup, tubuh akan memberikan respon psikologis. Hal ini sesui dengan teori Jelani (2009) dimana salah satu efektivitas kandungan kimia dalam minyak esensial dapat mempengaruhi aktivitas fungsi kerja otak melalui sistem saraf yang berhubungan dengan indera penciuman. Respon ini akan merangsang peningkatan aktivitas neutrotransmiter, yaitu berkaitan dengan pemulihan kondisi psikologis seperti emosi, perasaan, pikiran, dan keinginan.

\section{KESIMPULAN}

Kesimpulan dalam penelitian ini adalah rata-rata kecemasan menghadapi persalinan pada ibu hamil trimester III sebelum diberikan aromaterapi lavender adalah 18,07 dengan nilai maksimum 22 dan nilai minium 14. Rata-rata kecemasan menghadapi persalinan pada ibu hamiltrimester III setelah diberikan aromaterapi lavender adalah 14,53 dengan nilai maksimum 18 dan nilai minimum 10. Aromaterapi lavender efektif untuk menurunkan kecemasan menghadapi persalinan pada ibu hamil trimester III dengan nilai p $0,000<$ 0,05 .

\section{DAFTAR PUSTAKA}

Ali, Babar dkk. (2015). Essential Oils Used in Aromatherapy: A systemic review. Asian Pac J Trop Biomed 2015; 5(8): 601-611. Diakses pada tanggal 15 Juli 2019.

http://www.sciencedirect.com/scie nce/article/pii/S22211691150010 33. 
Bastard, Janed dan Denise Tiran. (2006). Aromatherapy and massage for antenatal anxiety: Its effect on the fetus. Complementary Therapies in Clinical Practice (2006) 12, 4854. Diakses pada tanggal 15 Juli 2019.

https://www.researchgate.net/publ ication/7369453_Aromatherapy_a nd_massage_for_antenatal_anxiet y_Its_effect_on_the_fetus.

Cho, Mi-Yeon dkk. (2013). Effects of Aromatherapy on the Anxiety, Vital Signs, and Sleep Quality of Percutaneous Coronary Intervention Patients in Intensive Care Units. Evidence-Based Complementary and Alternative Medicine Volume 2013, Article ID 381381, 6 pages. Diakses pada tanggal 15 Juli 2019. http://www.hindawi.com/journals/ ecam/2013/381381/.

Dinas Kesehatan Kabupaten Semarang. (2017). Profil Kesehatan Kabupaten Semarang Tahun 2017.

Efitriasih, Heni. (2017). Pengaruh Endorphine Massage Terhadap Kecemasan Ibu Hamil Trimester III Dalam Menghadapi Persalinan di Pusekesmas Ungaran. (Skripsi). Ungaran. Universitas Ngudi Waluyo.

Jaelani. (2017). Aroma Terapi. Jakarta: Pustaka Populer Obor.

Mardjan. (2016). Pengaruh Kecemasan Pada Kehamilan Primipara Remaja. Abrori Institute.

Namazi, Masoumeh dkk. (2014). Aromatherapy With Citrus Aurantium Oil and Anxiety During the First Stage of Labor. Iran Red Crescent Med DOI: 10.5812/ircmj.18371. Diakses pada tanggal 15 Juli 2019. http://www.ncbi,nlm.nih.gov/pmc/ articles/PMC4102991/.
Notoatmojo, S. (2012). Metode Penelitian Kesehatan. Jakarta: Rineka Cipta.

Nurgiwiati, Endeh. (2015). Terapi Alternatif \& Komplementer Dalam Bidang Keperawatan. Bogor: In Media.

Pudiastuti, Ratna D. (2012). Asuhan Pada Ibu Hamil Normal dan Patologi. Yogyakarta: Nuha Medika.

Pusat Studi Biofarmaka LPPM IPB, dan Gagas Ulung. (2016). Sehat Alami dengan Herbal 250 Tanaman Herbal Sebagai Obat +60 Resep Menu Kesehatan. Jakarta: PT Gramedia Pustaka Utama.

Setiati, Nova dkk. (2019). Efektivitas Pemberian Aromaterapi Lavender untuk Menurunkan Kecemasan Ibu Hamil Trimester III dalam Persiapan Menghadapi Persalinan di Bidan Praktek Mndiri Nurussyifa Kecematan Buniseuri Ciamis. Jurnal Kesehatan Bakti Tunas Husada Vol 19 No1. Diakses pada tanggal 4 April 2019. http://ejurnal.stikesbth.ac.id/index.php/P3M_JKBTH/ article/view/449.

Sianipar, Kandace dkk. (2017). Pengaruh Aromaterapi, Relaksasi Otot Progresif Terhadap Penurunan Kecemasan Ibu Hamil Menjelang Persalinan di BPM Simalungun. Jurnal Ilmiah PANNMED Vol 12 No. 1. Diakses pada tanggal 18 Desember 2018. http://poltekkesmedan.e.journal.id/pannmed/artic le/view/55.

Suprijati. (2014). Efektivitas Pemberian Aromaterapi Untuk Menurunkan Kecemasan Ibu Hamil Trimester III dalam Persiapan Menghadapi Persalinan di Bidan Praktek Mandiri Suprijati Desa Bagi Kecamatan/Kabupaten Madiun. Jurnal Delima Harapan Vol 2 No. 
1. Diakses pada tanggal 18 Desember 2018. http://www.google.com/amp/s/doc player.info/amp/35520189-

Efektivitas-pemberianaromaterapi-untuk-menurunkankecemasan-ibu-hamil-trimesteriii-dalam-persiapan-menghadapipersalinan.html.

Susanti, N. (2008). Psikologi Kehamilan. Jakarta : EGC.

Widiono. (2013). Aromaterapi Inhalasi Sebagai Evidence Based Nursing pada Pasien GGK yang Menjalani Hemodialisa untuk Mengurangi
Kecemasan. Mahasiswa Megister Keperawatan Peminatan Medikal Bedah Universitas Gadjah Mada Yogyakarta. Diakses pada tanggal $22 \quad$ Mei 2019. http://www.google.com/amp/s/doc player.info/amp/29754791 Aromaterapi-inhalasi-sebagaievidence-based-nursing-padapasien-ggk-yang-menjalanihemodialisa-untuk-mengurangikecemasan.html.

Yohana, Yovita \& Yessica. (2011). Kehamilan dan Persalinan. Jakarta: Garda Media. 